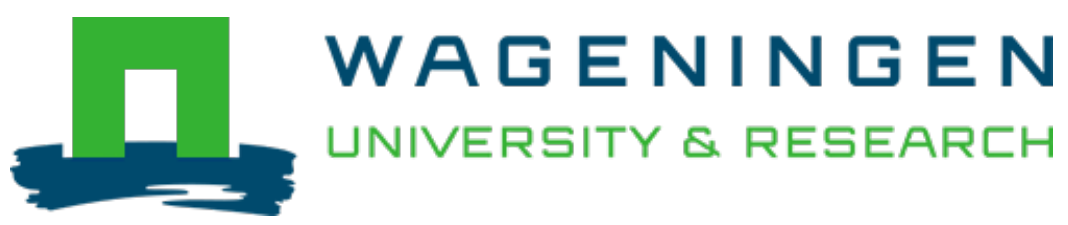

\title{
Rhizopus oligosporus biomass, sporangiospore yield and viability as influenced by harvesting age and processing conditions
}

\author{
Food Microbiology \\ Thanh, N.V.; Nout, M.J.R. \\ https://doi.org/10.1006/fmic.2001.0450
}

This publication is made publicly available in the institutional repository of Wageningen University and Research, under the terms of article $25 \mathrm{fa}$ of the Dutch Copyright Act, also known as the Amendment Taverne. This has been done with explicit consent by the author.

Article 25 fa states that the author of a short scientific work funded either wholly or partially by Dutch public funds is entitled to make that work publicly available for no consideration following a reasonable period of time after the work was first published, provided that clear reference is made to the source of the first publication of the work.

This publication is distributed under The Association of Universities in the Netherlands (VSNU) 'Article $25 \mathrm{fa}$ implementation' project. In this project research outputs of researchers employed by Dutch Universities that comply with the legal requirements of Article $25 \mathrm{fa}$ of the Dutch Copyright Act are distributed online and free of cost or other barriers in institutional repositories. Research outputs are distributed six months after their first online publication in the original published version and with proper attribution to the source of the original publication.

You are permitted to download and use the publication for personal purposes. All rights remain with the author(s) and / or copyright owner(s) of this work. Any use of the publication or parts of it other than authorised under article $25 \mathrm{fa}$ of the Dutch Copyright act is prohibited. Wageningen University \& Research and the author(s) of this publication shall not be held responsible or liable for any damages resulting from your (re)use of this publication.

For questions regarding the public availability of this publication please contact openscience.library@wur.nl 


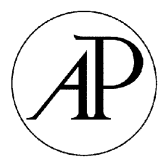

\title{
Rhizopus oligosporus biomass, sporangiospore yield and viability as influenced by harvesting age and processing conditions
}

\author{
N. V. Thanh and M. J. R. Nout*
}

The objective of tempe starter preparation is to obtain the maximum viable sporangiospores that can be stored in dry conditions without significant loss of viability. The aim of this research was to establish relationships between spore-harvesting age, their numbers, yield, viability and survival of processing and storage conditions. Within 6 days of incubation on cooked rice substrate, about $8 \% \mathrm{w} / \mathrm{w}$ of fungal biomass was formed, containing $6.3 \times 10^{9}$ spores per gram. Of these spores, only 5-6\% were viable. The remaining spores did not show damage to cytoplasmic membranes, and were probably dormant. Of the processing conditions, mild oven-drying had little negative effect on viability, unlike pulverization which caused mechanical damage and loss of viability. The age of spores at harvest influences their storage stability. This is evidenced by spores harvested after 3 days suffering bigger losses during 2 and 3 months storage compared to spores harvested after 4 or 5 days.

(C) 2002 Elsevier Science Ltd.

\section{Introduction}

Tempe (also spelled tempeh) is a mould-fermented soybean product originating from Indonesia (Ko and Hesseltine 1979, Usmani and Noorani 1986, Nout and Rombouts 1990). Because of its excellent nutritional properties and its agreeable taste, it is gaining increasing popularity in other regions. Whereas much tempe is still made using the traditional mixed-strain fungal cultures on plant leaves (Nout et al.1992), the use of defined tempe starter cultures has the advantage of selecting high quality strains. Several studies on the prepa-

*Corresponding author. Laboratory of Food $\mathrm{Mi}$ crobiology, Wageningen University, PO Box 8129, 6700 EV Wageningen, The Netherlands. Fax: +31 317 484978. E-mail: rob.nout@micro.fdsci.wag-ur.nl ration of tempe starter cultures have been reported previously (Hesseltine et al. 1976, Lotong and Suwanarit 1983, Shambuyi et al.1992). Steinkraus et al. (1965) reported the preservation of freeze-dried fermented soybeans for use as inoculum. Rusmin and Ko (1974) developed the inoculum by growing Rhizopus oligosporus on cooked rice. The mass production of spores using rice, pearled wheatbran and cracked soybean, and preservation of the spores after freeze-drying and grinding of the fermented mass was also reported (Wang et al. 1975). The rice inoculum produced more spores and had a longer shelf-life (4 months at 25$30^{\circ} \mathrm{C}$ ) than spores grown on tapioca waste, or on mixtures of tapioca waste and soybean flour as reported by Tanuwidjaja and Roestamsjah (1985). Rice-based starters were reported to yield tempe of higher acceptability; however,
Received:

29 November 2000

Department of Agrotechnology and Food Sciences, Wageningen University, 6700 EV Wageningen, The Netherlands 
they had a shorter shelf-life $(2 \cdot 5$ months $)$ compared to soya bean-based starters (7 months) as reported by Tunçel et al. (1989).

This study was designed to evaluate the effect of processing conditions such as incubation period, dehydration and pulverization on biomass formation and its spore-forming productivity, and the viability of the resulting rice-based tempe starter culture.

\section{Materials and Methods}

\section{Culture}

Rhizopus oligosporus LU 575 (NRRL 5905) was grown and maintained on malt extract agar (MEA, Oxoid CM 59) slants. Incubation was at $30^{\circ} \mathrm{C}$ for 1 week and storage was at $5^{\circ} \mathrm{C}$.

\section{Preparation of inoculum for the starter culture}

Spores from the slants mentioned above were inoculated onto the surface of MEA in $90-\mathrm{mm}$ Petri dishes and incubated at $30^{\circ} \mathrm{C}$ for 1 week. Spores of $R$. oligosporus were harvested by adding $10 \mathrm{ml}$ of sterile distilled water containing $0 \cdot 1 \%(\mathrm{v} / \mathrm{v})$ Tween 80 on to the surface of the culture and gently rubbing with a sterile bent glass rod. The spore suspension was removed from the culture and the flooding procedure was repeated twice. Pooled suspension was diluted with sterile water to give approximately $10^{5}$ spores per ml. This suspension ('A') was used as inoculum for substrate used to prepare tempe starter culture.

\section{Procedure for making tempe starter}

Solid state fermentation of polished broken rice was used to prepare the tempe starter culture. In each $1000-\mathrm{ml}$ Roux bottle, $50 \mathrm{~g}$ of rice and distilled water $(0 \cdot 6 \mathrm{~g}$ per gram of dry substrate) were mixed and allowed to stand at room temperature for $1 \mathrm{~h}$ with frequent shaking.

The cotton-plugged Roux bottles were steamsterilized for $20 \mathrm{~min}$ at $121^{\circ} \mathrm{C}$. The bottles were taken from the autoclave and shaken until the rice broke loose, or the rice was broken up with a spatula aseptically. The sterilized rice was allowed to cool to room temperature.

To add a nitrogen source and adjust the $\mathrm{pH}$ to 4 , volumes of $1.5 \mathrm{ml}$ of sterilized ammonium sulphate $1.5 \mathrm{M}$ solution $\left(0 \cdot 0067 \mathrm{~g}\left(\mathrm{NH}_{4}\right)_{2} \mathrm{SO}_{4}\right.$ per gram of dry substrate) and $1 \mathrm{ml}$ of sterilized $\mathrm{H}_{2} \mathrm{SO}_{4} 0.5 \mathrm{M}$ solution were added to the sterilized rice.

Each batch of sterilized rice $(50 \mathrm{~g})$ was inoculated and thoroughly mixed with $0.4 \mathrm{ml}$ of R. oligosporus spore suspension 'A' (about 1250 spores per gram of dry substrate). The number of spores per gram of dry substrate was chosen on the basis of previous trials. The inoculated substrate was spread in $0.5-\mathrm{cm}$ layers in the Roux bottles, which had sterile cotton plugs covered with aluminum foil perforated by puncturing.

The inoculated rice was incubated at $40^{\circ} \mathrm{C}$ for $2 \mathrm{~h}$, followed at $30^{\circ} \mathrm{C}$, for $2-6$ days, during which time the rice was covered with mycelium and black spores. Cultures were harvested after $2,3,4,5$ and 6 days of incubation to determine the effect of harvesting age on biomass, spore yield and viability.

\section{Drying and grinding}

The mouldy mass was broken up and transferred into sterile Petri dishes. The entire mass of substrate, mycelium and spores was dried at a mild temperature of $42^{\circ} \mathrm{C}$ for $48 \mathrm{~h}$ using a forced-air oven.

The dried material was then ground in a disinfected sample grinder (Fritsch, type Pulverisette 14, Germany with a $1.0-\mathrm{mm}$ screen treated with ethanol $70 \%$ ) at high speed for a short time to obtain a fine powder, and this was stored in air at $40 \%$ relative humidity for 1 day. The samples were analysed in triplicate.

\section{Spore yield}

Microscopic counts were made at harvest (2, 3, 4,5 and 6 days after inoculation) and after drying and grinding. One gram of the sample was placed in $99 \mathrm{ml}$ of sterile distilled water containing $0 \cdot 1 \%(\mathrm{v} / \mathrm{v})$ Tween 80 . The extraction of spores was carried out by vigorous agitation. The spore suspensions were diluted as appro- 
priate and counted using a Bürker-Türk counting chamber.

\section{Viability}

Viable spores were determined as colony forming units by surface-plating triplicate $0 \cdot 1-\mathrm{ml}$ aliquots on Rose Bengal chloramphenicol agar base (RBCC; Oxoid CM 549) with addition of $0 \cdot 2 \mathrm{gl}^{-1}$ Rose Bengal (Fluka AG, Switzerland) and on malt extract agar (MEA; Oxoid, CM 59). After incubation at $37^{\circ} \mathrm{C}$ and $30^{\circ} \mathrm{C}$, respectively, for 1-2 days, colonies were counted.

\section{Fluorescent markers}

The $R$. oligosporus spore suspensions were washed twice by centrifugation in an Eppendorf centrifuge in phosphate buffer $\left(\mathrm{K}_{2} \mathrm{HPO}_{4}\right.$ $50 \mathrm{~mm}$ adjusted to $\mathrm{pH} 4.0$ with citric acid $50 \mathrm{~mm})$. Subsequently, the suspensions were incubated for $20 \mathrm{~min}$ in the presence of 5 (and 6-)carboxyfluorescein diacetate (Molecular Probes Europe, Leiden, The Netherlands), $10 \mathrm{mg} \mathrm{ml}^{-1}$ acetone (cFDA $0.22 \mathrm{~mm}$ ) or propidium iodide (Sigma Chemical Co, St. Louis, USA) (PI $1.5 \mathrm{~mm}$ ) at $40^{\circ} \mathrm{C}$. They were then put on ice and counted in a Bürker-Türk counting chamber using fluorescence microscopy, using an Axioskop epifluorescence microscope equipped with a $50-\mathrm{W}$ mercury arc lamp, a fluorescein isothiocyanate filter set (excitation wavelength $450-490 \mathrm{~nm}$; emission wavelength $>520 \mathrm{~nm}$ ), a $\times 1001.3$ numerical aperture Plan-Neofluar objective lens, and a camera (Carl Zeiss, Oberkochen, Germany).

\section{Fungal biomass}

Biomass of the mould was determined by enzymatic digestion of the mouldy rice substrate and weighing of the undissolved residue using sterile cooked rice and purified mycelium as controls. The digestion protocol was described earlier by Kiers et al. (2000); specifically, step 1 of their in vitro digestion method was used, involving subsequent incubation with artificial saliva for $30 \mathrm{~min}$, with artificial gastric juice at $\mathrm{pH} 4.0$ for $60 \mathrm{~min}$, and with pancreatic solution at $\mathrm{pH} 6.0$ for $30 \mathrm{~min}$, all at $37^{\circ} \mathrm{C}$.
The estimated weight of mould biomass in moulded rice was calculated as

$$
M=\left(R_{0}-R_{1}\right) / R_{m}
$$

in which $M=$ biomass of the mould in the moulded rice; $R_{0}=$ residue of moulded rice after enzymatic digestion; $R_{1}=$ residue of control cooked rice after enzymatic digestion; and $R_{\mathrm{m}}=$ residue of pure mycelium grown on MEA (dried and ground), after enzymatic digestion.

The accuracy of the biomass estimation is $90-95 \%$.

\section{Statistical analysis}

Experiments were in duplicate, analyses in triplicate. The results were reported as means of triplicates with standard deviation using the unrelated $t$-test to test significance of differences.

\section{Results and Discussion}

\section{Effect of harvesting age on biomass, number and viability of sporangiospores of $R$. oligosporus}

Table 1 summarizes biomass content of the moulded rice, and the number and viability of spores harvested after 2-6 days of incubation. A comparison is made of freshly harvested and processed spores. During the first day of incubation, the inoculated spores germinated and the subsequent growth covered the rice lumps with a white, woolly mycelial layer. On the second day the colour turned to light grey due to the formation of sporangia. During the following days more sporangia were formed and the colour of the mass changed to dark grey. From day 5 the mass began to change to a brownish colour.

A gradual increase of biomass was observed until 5 days, when a maximum was reached. This was followed by a decrease that coincided with the development of a brownish colour, both of which may be due to nutrient depletion. After 2 days of cultivation the majority of microscopically visible sporangiospores had been formed, but it took up to 4 days of cultivation to achieve the highest level of viability of the spores. 
It should be noted that rather low levels of viability (6\% of the total number of spores) were obtained.This appears significantly lower than the viability of $69 \%$ reported by Rusmin and Ko (1974). However, their absolute number of germinating spores was of a similar order of magnitude, and they quantified germinating spores microscopically. Other discrepancies may arise from sensitivity to processing (drying and pulverizing) as well as aggregation causing single colonies from multiple spores. It appeared that the older the spores harvested, the less resistant they were to processing. After 5 days or longer, the yield of viable processed spores decreased considerably.

\section{Effect of drying and pulverization on viability of sporangiospores}

Table 2 summarizes the effect of drying and pulverization on the viability of sporangio- spores of $R$. oligosporus harvested after 4 days. As this experiment was carried out separately at a later stage, corresponding values differ slightly from those in Table 1.

It was observed that, of the processing steps, drying caused only a slight reduction to $69 \%$ of the freshly harvested spores. Rusmin and Ko (1974) reported that, at the time the spores were prepared, the germination percentage was $69 \%$ in inoculum pieces. The present result is in agreement with these studies of semi-pure starter culture using a rice substrate. On the other hand, pulverizing caused a higher reduction of the number of visible sporangiospores. The same trend was seen when looking at the viable spores (RBCC).

Fluorescence with cFDA indicates esterase activity within the spores. This fluorescent marker has been used in several yeasts and other micro-organisms as an indicator for metabolic activity. Breeuwer et al. (1997) reported

Table 1. Effect of harvesting age on biomass, number and viability of sporangiospores of R. oligosporus

\begin{tabular}{|c|c|c|c|c|c|c|c|}
\hline \multirow{2}{*}{$\begin{array}{l}\text { Incubation } \\
\text { (days) }\end{array}$} & \multirow{2}{*}{$\begin{array}{l}\text { Biomass }^{1} \\
(\mathrm{w} / \mathrm{w})\end{array}$} & \multicolumn{3}{|c|}{ Harvested $^{2}$} & \multicolumn{3}{|c|}{ Dried, pulverized $^{3}$} \\
\hline & & $\begin{array}{c}\text { Visible spores } \\
\text { (microscopic) } \\
\text { Log } \mathrm{Ng}^{-1} \\
\text { dry weight }\end{array}$ & $\begin{array}{l}\text { Viable spores } \\
\text { (RBCC) } \\
\text { Log cfu g }{ }^{-1} \\
\text { dry weight }\end{array}$ & $\begin{array}{c}\text { Viability } \\
\text { of visible } \\
\text { spores }(\%)\end{array}$ & $\begin{array}{c}\text { Visible spores } \\
\text { (microscopic) } \\
\text { Log } \mathrm{Ng}^{-1} \\
\text { dry weight }\end{array}$ & $\begin{array}{l}\text { Viable spores } \\
\text { (RBCC) } \\
\text { Log cfu g }{ }^{-1} \\
\text { dry weight }\end{array}$ & $\begin{array}{c}\text { Viability } \\
\text { of visible } \\
\text { spores (\%) }\end{array}$ \\
\hline 2 & $5 \cdot 76(0 \cdot 06)^{\mathrm{a}}$ & $9 \cdot 13(0 \cdot 10)^{\mathrm{a}}$ & $7 \cdot 54(0 \cdot 02)^{\mathrm{a}}$ & $2 \cdot 8$ & $8 \cdot 77(0 \cdot 06)^{\mathrm{a}}$ & $6 \cdot 40(0 \cdot 09)^{\mathrm{a}}$ & $4 \cdot 3$ \\
\hline 3 & $6 \cdot 79(0 \cdot 32)^{\mathrm{a}}$ & $9 \cdot 63(0 \cdot 08)^{b}$ & $8 \cdot 12(0 \cdot 06)^{b}$ & $3 \cdot 0$ & $9 \cdot 09(0 \cdot 15)^{\mathrm{b}}$ & $7 \cdot 74(0 \cdot 11)^{\mathrm{bc}}$ & $4 \cdot 4$ \\
\hline 4 & $7 \cdot 71(0 \cdot 30)^{\mathrm{b}}$ & $9 \cdot 65(0 \cdot 03)^{\mathrm{b}}$ & $8 \cdot 43(0 \cdot 07)^{\mathrm{c}}$ & $6 \cdot 0$ & $9 \cdot 24(0 \cdot 02)^{\mathrm{bc}}$ & $7 \cdot 86(0 \cdot 09)^{b}$ & $4 \cdot 2$ \\
\hline 5 & $8 \cdot 17(0 \cdot 08)^{b}$ & $9 \cdot 72(0 \cdot 12)^{\mathrm{bc}}$ & $8 \cdot 39(0 \cdot 04)^{c}$ & $4 \cdot 6$ & $9 \cdot 35(0 \cdot 10)^{\mathrm{c}}$ & $7 \cdot 81(0 \cdot 04)^{b}$ & $2 \cdot 8$ \\
\hline 6 & $8 \cdot 11(0 \cdot 24)^{b}$ & $9 \cdot 80(0 \cdot 07)^{\mathrm{c}}$ & $8 \cdot 39(0 \cdot 02)^{\mathrm{c}}$ & $4 \cdot 0$ & $9 \cdot 49(0 \cdot 24)^{\mathrm{c}}$ & $7 \cdot 71(0 \cdot 03)^{\mathrm{c}}$ & $1 \cdot 7$ \\
\hline
\end{tabular}

Values are mean(s.d.) of triplicates.

${ }^{1}$ Biomass dry weight $\%$ in moulded rice.

${ }^{2}$ Analysed immediately after harvest.

${ }^{3}$ Analysed after $24 \mathrm{~h}$ equilibration period at $21^{\circ} \mathrm{C}$.

In each column, the data denoted with the same letter are not significantly different $(P \leq 5 \%$, one tail unrelated $t$-test).

Table 2. Effect of drying and pulverization on viability of sporangiospores of Rhizopus oligosporus harvested after 4 days

\begin{tabular}{|c|c|c|c|c|}
\hline & $\begin{array}{c}\text { Visible spores } \\
\text { Log } \mathrm{Ng}^{-1} \\
\text { dry weight }\end{array}$ & $\begin{array}{l}\text { Viable spores (RBCC) } \\
\text { Log cfu }{ }^{-1} \text { dry weight }\end{array}$ & $\begin{array}{l}\text { Fluorescent spores } \\
\text { (cFDA) Log } \mathrm{Ng}^{-1} \\
\text { dry weight }\end{array}$ & $\begin{array}{c}\text { Fluorescent spores (PI) } \\
\text { Log } \mathrm{Ng}^{-1} \\
\text { dry weight }\end{array}$ \\
\hline Harvested & $9 \cdot 47(0 \cdot 03)^{\mathrm{a}}$ & $8 \cdot 29(0 \cdot 04)^{\mathrm{a}}$ & $8 \cdot 35(0 \cdot 03)^{\mathrm{a}}$ & $7 \cdot 54(0 \cdot 09)^{\mathrm{a}}$ \\
\hline Dried & $9 \cdot 45(0 \cdot 02)^{\mathrm{a}}$ & $8 \cdot 13(0 \cdot 08)^{b}$ & $8 \cdot 18(0 \cdot 02)^{b}$ & $7 \cdot 24(0 \cdot 07)^{\mathrm{b}}$ \\
\hline Pulverized & $9 \cdot 04(0 \cdot 04)^{\mathrm{b}}$ & $7 \cdot 43(0 \cdot 02)^{\mathrm{c}}$ & $7 \cdot 33(0 \cdot 09)^{\mathrm{c}}$ & $7 \cdot 33(0 \cdot 06)^{b}$ \\
\hline
\end{tabular}

Values are mean(s.d.) of triplicates.

In each column, the data denoted with the same letter are not significantly different $(P \leq 5 \%$, one tail unrelated $t$-test). 
that the viability of $R$. oligosporus sporangiospores could be assessed by fluorescence techniques (cFDA), and that the fluorescence intensity of the spores could be used as an indication of metabolic (enzymatic) activity. Spores which are not fluorescent did not germinate. The results reported here are in general agreement with those of Breeuwer et al. (1997). In the present study, it appears that the loss of viability measured on RBCC is very well correlated with the same trend in fluorescence with cFDA. However, not all fluorescent spores formed colonies. We assume that colonies were formed by those spores emitting stronger fluorescence intensity.

The fluorescence marker PI can enter cells in which the cytoplasmic membranes have been damaged. This can be useful as a marker for dead cells. The strong decrease of cFDA value was accompanied by an increase of dead spores as observed with PI. This confirms that drying and particularly pulverizing are important causes of decreasing viability of spores. In the present study, the number of spores that give a fluorescent reaction with PI is quite low, which would indicate that loss of membrane integrity is not the primary reason for the low level of viability of the sporangiospores. Alternatively, it could be that PI is not an appropriate marker for $R$. oligosporus and that other fluorescent markers for membrane integrity give higher values. This should be tested in future.

In conclusion, it is likely that the majority of sporangiospores tested are in a state of dormancy, having intact membranes but lacking enzyme activity.

\section{Effect of harvesting age and storage conditions on viability}

Table 3 shows the effects of harvesting age and storage conditions on viability of processed (dried and pulverized) sporangiospores of $R$. oligosporus.

On the whole, the storage experiment showed that spores retained their viability slightly better at $30^{\circ} \mathrm{C}$ than at $5^{\circ} \mathrm{C}$. Spores harvested after 3 days lost more of their viability during storage, whereas there was no difference between days 4 and 5 . After 2 and 3

Table 3. Effect of harvesting age and storage conditions on viability of sporangiospores of Rhizopus oligosporus (dried and pulverized)

\begin{tabular}{|c|c|c|c|c|c|c|c|}
\hline \multirow{2}{*}{$\begin{array}{l}\text { Harvest } \\
\text { age } \\
\text { (days) }\end{array}$} & \multirow{2}{*}{$\begin{array}{l}\text { Storage } \\
\text { period } \\
\text { (months) }\end{array}$} & \multicolumn{3}{|c|}{ Storage temperature of $5^{\circ} \mathrm{C}$} & \multicolumn{3}{|c|}{ Storage temperature of $30^{\circ} \mathrm{C}$} \\
\hline & & $\begin{array}{l}\text { Viable spores } \\
\text { (RBCC) } \\
\text { Log cfu g }^{-1} \\
\text { dry weight }\end{array}$ & $\begin{array}{l}\text { Viable spores } \\
\text { (MEA) } \\
\text { Log cfu g }{ }^{-1} \\
\text { dry weight }\end{array}$ & $\begin{array}{c}\text { Fluorescent } \\
\text { spores (cFDA) } \\
\text { Log } \mathrm{Ng}^{-1} \\
\text { dry weight }\end{array}$ & $\begin{array}{l}\text { Viable spores } \\
\text { (RBCC) } \\
\text { Log cfu g } \\
\text { dry weight }\end{array}$ & $\begin{array}{c}\text { Viable spores } \\
\text { (MEA) } \\
\text { Log cfu g }{ }^{-1} \\
\text { dry weight }\end{array}$ & $\begin{array}{c}\text { Fluorescent } \\
\text { spores (cFDA) } \\
\text { Log } \mathrm{Ng}^{-1} \\
\text { dry weight }\end{array}$ \\
\hline 3 & $\begin{array}{l}0^{1} \\
1 \\
2 \\
3\end{array}$ & $\begin{array}{l}7 \cdot 74(0 \cdot 11)^{\mathrm{a}} \\
6 \cdot 82(0 \cdot 02)^{\mathrm{b}} \\
6 \cdot 77(0 \cdot 03)^{\mathrm{c}} \\
6 \cdot 59(0 \cdot 04)^{\mathrm{d}}\end{array}$ & $\begin{array}{l}\text { nd } \\
\text { nd } \\
7 \cdot 4 \\
6 \cdot 8\end{array}$ & $\begin{array}{l}\text { nd } \\
\text { nd } \\
7 \cdot 5 \\
7 \cdot 2\end{array}$ & $\begin{array}{l}7 \cdot 74(0 \cdot 11)^{\mathrm{a}} \\
6 \cdot 87(0 \cdot 03)^{\mathrm{b}} \\
6 \cdot 80(0 \cdot 06)^{\mathrm{b}} \\
6 \cdot 81(0 \cdot 08)^{\mathrm{b}}\end{array}$ & $\begin{array}{l}\text { nd } \\
\text { nd } \\
7 \cdot 2 \\
6 \cdot 7\end{array}$ & $\begin{array}{l}\text { nd } \\
\text { nd } \\
7 \cdot 4 \\
7 \cdot 2\end{array}$ \\
\hline 4 & $\begin{array}{l}0^{1} \\
1 \\
2 \\
3\end{array}$ & $\begin{array}{l}7 \cdot 86(0 \cdot 09)^{\mathrm{e}} \\
7 \cdot 40(0 \cdot 07)^{\mathrm{f}} \\
7 \cdot 39(0 \cdot 07)^{\mathrm{f}} \\
7 \cdot 10(0 \cdot 02)^{\mathrm{g}}\end{array}$ & $\begin{array}{l}\text { nd } \\
\text { nd } \\
7 \cdot 7 \\
7 \cdot 0\end{array}$ & $\begin{array}{l}\text { nd } \\
\text { nd } \\
7 \cdot 6 \\
7 \cdot 3\end{array}$ & $\begin{array}{l}7 \cdot 86(0 \cdot 09)^{\mathrm{c}} \\
7 \cdot 31(0 \cdot 07)^{\mathrm{d}} \\
7 \cdot 26(0 \cdot 04)^{\mathrm{d}} \\
7 \cdot 23(0 \cdot 03)^{\mathrm{d}}\end{array}$ & $\begin{array}{l}\text { nd } \\
\text { nd } \\
7 \cdot 5 \\
7 \cdot 3\end{array}$ & $\begin{array}{l}\text { nd } \\
\text { nd } \\
7 \cdot 7 \\
7 \cdot 4\end{array}$ \\
\hline 5 & $\begin{array}{l}0^{1} \\
1 \\
2 \\
3\end{array}$ & $\begin{array}{l}7 \cdot 81(0 \cdot 04)^{\mathrm{h}} \\
7 \cdot 28(0 \cdot 02)^{\mathrm{i}} \\
7 \cdot 23(0 \cdot 02)^{\mathrm{j}} \\
7 \cdot 03(0 \cdot 02)^{\mathrm{k}}\end{array}$ & $\begin{array}{l}\text { nd } \\
\text { nd } \\
7 \cdot 5 \\
7 \cdot 2\end{array}$ & $\begin{array}{l}\text { nd } \\
\text { nd } \\
7 \cdot 4 \\
7 \cdot 2\end{array}$ & $\begin{array}{l}7 \cdot 81(0 \cdot 04)^{\mathrm{e}} \\
7 \cdot 29(0 \cdot 06)^{\mathrm{f}} \\
7 \cdot 26(0 \cdot 05)^{\mathrm{f}} \\
7 \cdot 10(0 \cdot 08)^{\mathrm{g}}\end{array}$ & $\begin{array}{l}\text { nd } \\
\text { nd } \\
7 \cdot 6 \\
7 \cdot 2\end{array}$ & $\begin{array}{l}\text { nd } \\
\text { nd } \\
7 \cdot 4 \\
7 \cdot 4\end{array}$ \\
\hline
\end{tabular}

Values are mean(s.d.) of triplicates.

nd, not determined.

${ }^{1}$ Moisture content of the stored samples was $\approx 7 \cdot 5 \%$.

In each column, the data denoted with the same letter are not significantly different $(P \leq 5 \%$, one tail unrelated $t$-test). 
months of storage, verifications using MEA and cFDA showed that, on a less specific medium such as MEA, the same order of magnitude of viability was observed. Likewise, spore fluorescence was maintained after 3 months of storage. Storage was also carried out under nitrogen. This gave very similar results (data not shown).

In conclusion, the following general remarks can be made: first, there is an age effect, which is reflected in a maximum of viability of spores and a different resistance to processing conditions; second, drying at mild temperatures, such as those used in this study, gives very little loss of viability; third, on the other hand, pulverization can give rise to considerable losses, so this is a step that can and must be optimized for practical applications; fourth, the majority of spores were in a 'dormant' stage and it will be of interest to study the nature of this dormancy; fifth, cFDA fluorescence gives a very good correlation with culturing viability.

\section{References}

Breeuwer, P., De Reu, J. C., Drocourt, J. L., Rombouts, F. M. and Abee, T. (1997) Nonanoic acid, a fungal self-inhibitor, prevents germination of Rhizopus oligosporus sporangiospores by dissipation of the pH gradient. Appl. Env. Microbiol. 63, 178-185.

Hesseltine, C.W., Swain, E. W. and Wang, H. L. (1976) Production of fungal spores as inocula for oriental fermented foods. Dev. Industr. Microbiol. 17, 101-115.

Kiers, J. L., Nout, M. J. R. and Rombouts, F. M. (2000) In vitro digestibility of processed and fermented soya bean, cowpea and maize. J. Sci. Food Agric. 80, 1325-1331.

Ko, S. D. and Hesseltine, C. W. (1979) Tempe and related foods. In: Economic Microbiology, Vol. 4: Microbial Biomass (Ed. A. H. Rose), London, Academic Press. pp. 115-140.

Lotong, N. and Suwanarit, P. (1983) Production of soy sauce koji mold spore inoculum in plastic bags. App. Env. Microbiol. 46, 1224-1226.

Nout, M. J. R. and Rombouts, F. M. (1990) Recent developments in tempe research. J. Appl. Bacteriol. 69, 609-633.

Nout, M. J. R., Martoyuwono, T. D., Bonné, P. C. J. and Odamtten, G. T. (1992) Hibiscus leaves for the manufacture of Usar, a traditional inoculum for tempe. J. Sci. Food Agric. 58, 339-346.

Rusmin, S. and Ko, S. D. (1974) Rice-grown Rhizopus oligosporus inoculum for tempeh fermentation. Appl. Env. Microbiol. 28, 347-350.

Shambuyi, M., Beuchat, L. R., Hung, Y. C. and Nakayama, T. (1992) Evaluation of substrates and storage conditions for preparing and maintaining starter cultures for tempeh fermentation. Int. J. Food Microbiol. 15, 77-85.

Steinkraus, K. H., van Buren, J. P., Hackler, L. R. and Hand, D. B. (1965) A pilot-plant process for the production of dehydrated tempeh. Food Technol. 19, 63-68.

Tanuwidjaja, L. and Roestamsjah. (1985) Preparation and utilization of powder form inoculum for tempe fermentation. ASEAN Food J. 1, 22-24.

Tunçel, G., Nout, M. J. R. and Rombouts, F. M. (1989) Effect of acidification on the microbiological composition and performance of tempe starter. Food Microbiol. 6, 37-43.

Usmani, N. F. and Noorani, R. (1986) Studies on soybean tempeh. II. Propagation and preservation of Rhizopus oligosporus spores for commercial production of tempeh from soybean. Pakistan Journal of Scientific and Industrial Research 29, 148-150.

Wang, H. L., Swain, E. W. and Hesseltine, C. W. (1975) Mass production of Rhizopus oligosporus spores and their application in tempeh fermentation. J. Food Sci. 40, 168-170. 